\title{
MDM2 (T309G) Gene Polymorphism Determines the Susceptibility of Hepatocellular Carcinoma in Bangladesh
}

\author{
Md. Bayejid Hosen ${ }^{1,2}$, Narwana Khaleque ${ }^{3}$, Sajib Chakrabarty ${ }^{1}$, Mamun Al \\ Mahtab $^{4}$, Yearul Kabir ${ }^{1}$
}

${ }^{1}$ Department of Biochemistry and Molecular Biology, University of Dhaka, Bangladesh. ${ }^{2}$ National Forensic DNA Profiling Laboratory, Dhaka Medical College, Dhaka, Bangladesh. ${ }^{3}$ Sheikh Russel Gastroliver Institute \& Hospital, Dhaka, Bangladesh. ${ }^{4}$ Department of Hepatology, Bangabandhu Sheikh Mujib Medical University, Bangladesh.

\begin{abstract}
Background: Hepatocellular carcinoma (HCC) is one of the fatal cancer types worldwide, and a variety of genetic factors are considered to be associated with this incidence. MDM2 gene plays a pivotal role in various pathways, which are essential to combat tumor formation. The study aimed to find out the associations of MDM2 (T309G, rs2279744) gene polymorphism with the development of HCC in the Bangladeshi population. Methods: A case-control study on $100 \mathrm{HCC}$ patients and 110 control subjects was conducted. The genotyping of the MDM2 (T309G) gene was done using PCR-RFLP methods. Results: The percentage of TT and GG genotypes were significantly different $(\mathrm{p}<0.01)$ among the study subjects. There were four genotyping groups, while the subjects with TT genotypes were considered the reference group. Patients with GG genotypes were at high risk of developing HCC (OR, 3.6; $95 \%$ CI, 1.64-7.80; $<<0.01)$ compared to the control. On the other hand, the association of TG genotypes with HCC was not statistically significant (OR, 1.8; $95 \% \mathrm{CI}, 0.91-3.40, \mathrm{p}>0.05)$. In addition, patients having either GG or TG genotypes showed higher risk for HCC compared to control group $(\mathrm{OR}=2.20 ; 95 \% \mathrm{CI}=1.21-4.14 ; \mathrm{P}<0.05)$. Conclusion: Our study suggested that the MDM2 gene may have a strong association with the development of HCC, and the GG allele could serve as an essential determinant to identify the higher risk of HCC in the Bangladeshi population.
\end{abstract}

Keywords: Bangladesh- Hepatocellular carcinoma- MDM2- Polymorphism

Asian Pac J Cancer Biol, 6 (3), 213-217

\section{Introduction}

Hepatocellular carcinoma (HCC) is considered the fifth most common cancer worldwide, leading to over 600,000 deaths each year [1]. There are multiple risk factors, including chronic HBV or HCV infection, cirrhosis, excessive alcohol consumption, carcinogen exposure, and various genetic factors associated with $\mathrm{HCC}$ [2-5]. Genetic factors are accounted as inherited polymorphisms in the genes involved in cell-cycle regulation, DNA repair, and apoptosis $[6,7]$. Hepatocarcinogenic risk factors could be defined by the identification of polymorphism of modifier genes. Murine double minute 2 (MDM2) plays a vital role not only in the $\mathrm{p} 53$ pathway but also in various other pathways such as inhibition of retinoblastoma protein $(\mathrm{RB})$
Submission Date: 07/22/2021 Acceptance Date: 09/01/2021

Corresponding Author:

Prof. Yearul Kabir

Department Department of Biochemistry and Molecular Biology, University of Dhaka, Dhaka - 1000, Bangladesh.

Email: ykabir@yahoo.com 
described by Bond et al. (2004), which is referred to as SNP309 or T309G [17]. The exchange of T to $\mathrm{G}$ at 309 position of the $\mathrm{p} 53$-responsive intronic promoter augments the binding affinity of the Sp1 transcription activator, causing the increased level of MDM2, which directly inhibits p53 transcriptional activity facilitating the transcription of the damaged cells to escape from the cell-cycle checkpoint and become carcinogenic $[17,18]$. The MDM2 polymorphism has been associated with almost all forms of cancer. Several studies have reported that the MDM2 (T309G) polymorphism is associated with susceptibility to various tumors, including gastric carcinoma [19], non-small-cell lung cancer [20], endometrial cancer [21], sarcoma [17], and bladder cancer [22]. Some recent investigations have shown the association of MDM2 (T309G) polymorphism with the risk of HCC in Chinese [23], Japanese [24], Korean [25], and Turkish [26]. On the other hand, contradictory results were reported where no association between MDM2 (T309G) polymorphism and HCC had been shown in different populations [27, 28].

The study of underlying mechanisms of complex diseases such as cancer by identifying SNPs that alter the expression and function of genes contributing to the predisposition of diseases has become a prominent area of investigation. Since the interaction of MDM2 and TP53 plays pivotal roles in apoptotic cell death, DNA repair, and cell-cycle checkpoint, we hypothesized that the genetic polymorphism in MDM2 might contribute to the susceptibility to hepatocellular carcinogenesis. The MDM2 (T309G) gene polymorphism and its relationship with the susceptibility of HCC may vary in different populations to different ethnic groups, depending on different geographical areas and levels of environmental exposures. To the best of our knowledge, an association between MDM2 (T309G) polymorphism and HCC susceptibility has not yet been studied in the Bangladeshi population. The present study aimed to determine the effects of MDM2 (T309G) polymorphism on the risk of developing hepatocellular carcinoma in Bangladeshi people.

\section{Materials and Methods}

This study was conducted on 210 subjects, including 100 patients suffering from hepatocellular carcinoma and a total of 110 healthy control subjects (Table 1). We found no significant differences in baseline characteristics among the study subjects (Table 1). The HCC cancer patients who had no history of other chronic diseases were recruited from the Department of Hepatology of Bangabandhu Sheikh Mujib Medical University, Dhaka. The healthy controls subjects who don't have any history of cancer or chronic diseases were assigned in this study during their regular health check-up in different hospitals of Dhaka city (Table 1).

The nature of the study was explained among the participants, and informed consent from them was obtained. A structured questionnaire covering the information of age, gender, medical and family history of chronic diseases was completed. The ethical review committee (ERC) of the Department of Biochemistry and Molecular Biology, University of Dhaka, approved the study. In this study, the rules and regulations of the declaration of Helsinki and its subsequent revisions were followed [29].

\section{Sample collection}

All aseptic precautions were taken, and disposable syringes were used to draw approximately $3.0 \mathrm{~mL}$ of venous blood from each individual with the help of a trained phlebotomist. EDTA $(1.20 \mathrm{mg} / \mathrm{mL})$ containing tubes were used to collect the drawn blood and transferred immediately into the laboratory in an icebox and stored at $-20^{\circ} \mathrm{C}$ until genomic DNA extraction.

\section{Genotyping of MDM2 (T309G) Gene}

The MDM2 (T309G) genotypes were determined using our previously described PCR-RFLP method [30]. Bailes's method was followed to extract the genomic DNA from peripheral leukocytes [31]. Then the genomic DNA was amplified by polymerase chain reaction (PCR). PCR conditions and primer sequences were used according to the method of Walsh et al. (2007) [21]. The Go Taq polymerase from Promega Corporation, USA, was used to carry out PCR. Approximately $0.5 \mu \mathrm{g}$ of genomic DNA was added to a PCR mix which was composed of $200 \mu \mathrm{mol}$ dNTPs, 50 pmol of each primer, 2.5 units Taq polymerase, and PCR buffer consisting of $10 \mathrm{~mol} / \mathrm{mL}$ Tris- $\mathrm{HCl}(\mathrm{pH} 8.3), 2.5 \mathrm{~mol} / \mathrm{mL} \mathrm{MgCl} 2$ and $50 \mathrm{~mol} / \mathrm{mL}$ $\mathrm{KCl}$ in a volume of $50 \mu \mathrm{L}$.

About $10.0 \mu \mathrm{L}$ PCR product (352 bp) for T309G genotype was digested with MspA1I restriction enzyme (New England Biolabs, Ipswich, MA, USA) at $37^{\circ} \mathrm{C}$ for 30-60 $\mathrm{min}$. The $\mathrm{T} / \mathrm{T}, \mathrm{T} / \mathrm{G}$, and $\mathrm{G} / \mathrm{G}$ genotypes were identified as 233/88 bp, 233/187/88 bp, and 187/88 bp, respectively, running on the $3 \%$ agarose gel electrophoresis and the $46 \mathrm{bp}$ of the complete digestion of $233 \mathrm{bp}$ fragment could not be resolved (Figure 1).

\section{Statistical Analysis}

The Statistical Package for Social Science (SPSS), windows version 17.0, was used to perform statistical analysis. The odds ratios (ORs) were calculated to assess the relative association between cases and controls. As a measure of relative risk, ORs at $95 \%$ confidence intervals (95\% CI) were estimated using logistic regression models. The results were considered statistically significant when the $\mathrm{p}$-value is $<0.05$.

\section{Results}

This study examined the association of MDM2 (T309G) gene polymorphism as a risk factor for developing hepatocellular carcinoma. The baseline characteristics showed no significant difference between the two groups (Table 1). The age and gender between the control and cases have been matched. Moreover, the alcohol consumption data and family history showed no association with HCC in the Bangladeshi population. This is may be due to the law prohibiting alcohol 
Table 1. Baseline Characteristics

\begin{tabular}{lcc}
\hline & $\begin{array}{c}\text { Healthy Control } \\
(\mathrm{n}=110, \%)\end{array}$ & $\begin{array}{c}\text { HCC Patients } \\
(\mathrm{n}=100, \%)\end{array}$ \\
\hline Age & $47.5 \pm 13$ & $51.3 \pm 16$ \\
Gender & $89(81)$ & $78(78)$ \\
$\quad$ Male & $21(19)$ & $22(22)$ \\
$\quad$ Female & & \\
Alcohol intake & $02(1.8)$ & $02(2)$ \\
$\quad$ Yes & $108(98.2)$ & $98(98)$ \\
$\quad$ No & & \\
Family history of cancer & - & $15(15)$ \\
$\quad$ Yes & - & $65(65)$ \\
$\quad$ No & - & $20(20)$ \\
$\quad$ No comments &
\end{tabular}

Results are Expressed as Number (percentage) and Mean \pm SD

consumption in Bangladesh. The genotypic analysis was done and presented in Table 2 and Table 3.

\section{Genotypic distribution and analysis of MDM2 (T309G)} genotypes

Table 2 represents the genotype frequency of the MDM2 (T309G) gene in different study groups. The TT and GG genotypes were significantly different $(p<0.01)$ between the study subjects. The percentages of TT, TG, and GG alleles were $37.3 \%, 46.4 \%$, and $18.3 \%$, respectively, in control subjects. On the other hand, the percentages of TT, TG, and GG alleles were $21 \%, 46 \%$, and $33 \%$, respectively, in HCC patients.

The risk of developing HCC associated with the MDM2 (T309G) genotypes was estimated (Table 3). There were four genotyping groups, while the subjects with TT genotypes were considered the reference group. Patients with GG genotypes were at high risk of developing HCC (OR, 3.6; $95 \%$ CI, 1.64-7.80; $\mathrm{p}<0.01)$ compared to the control. On the other hand, an association of TG

Table 2. Genotypic Frequencies of MDM2 (T309G) Gene in Study Subjects

\begin{tabular}{lccc}
\hline Genotypes & $\begin{array}{c}\text { Controls subjects } \\
(\mathrm{n}=110, \%)\end{array}$ & $\begin{array}{c}\text { HCC patients } \\
(\mathrm{n}=100, \%)\end{array}$ & p value \\
\hline TT & $41(37.3)$ & $21(21)$ & $<0.01$ \\
TG & $51(46.4)$ & $46(46)$ & \\
GG & $18(16.3)$ & $33(33)$ & \\
\hline
\end{tabular}

Results are expressed as number (percentage). Chi-square test was performed. $\mathrm{p}<0.05$ was taken as level of significance.

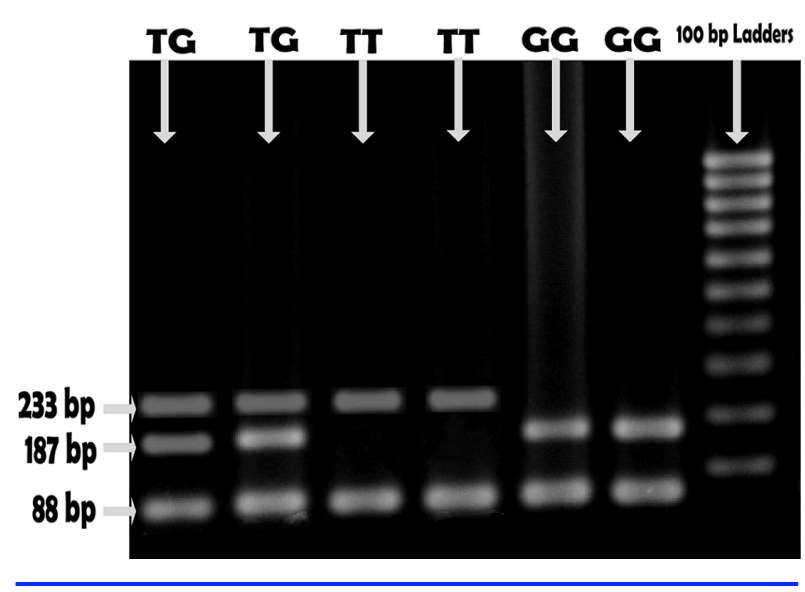

Figure 1. Banding Pattern of MDM2 (T309G) Gene in $3 \%$ Agarose Gel. Presence of 233/187/88 bd fragments, $233 / 88$ bp fragments and $187 / 88 \mathrm{bp}$ fragments illustrated the presence of TG, TT and GG genotypes respectively. Because of small size, the $46 \mathrm{bp}$ band of complete digestion of $233 \mathrm{bp}$ fragment could not be resolved.

genotypes with $\mathrm{HCC}$ was not statistically significant (OR, 1.8; $95 \%$ CI, 0.91-3.40, p>0.05). In addition, patients having either GG or TG genotypes showed higher risk for HCC compared to control group (OR $=2.20 ; 95 \% \mathrm{CI}$ $=1.21-4.14 ; \mathrm{p}<0.05)$.

\section{Discussion}

Our present study was a molecular epidemiologic case-control study where we examined whether the MDM2 (T309G) polymorphisms influence the risk of HCC in the Bangladeshi population. The T309G SNP (rs2279744) is situated in the intronic promoter region of the MDM2 gene, and our recent study revealed that T309G SNP was associated with the increased risk of HCC in the Bangladeshi population. This finding is consistent with previous studies where the $\mathrm{T} 309 \mathrm{G}$ allele has been reported as the risk allele for $\operatorname{HCC}[23,24,32]$, and also suggests that the MDM2 T309G polymorphism may be used as one of the biomarkers for genetic susceptibility to HCC.

The association of MDM2 T309G polymorphism with hepatocellular carcinoma susceptibility has been shown previously $[17,18,23,24,27,28]$. In recent studies by Qiu et al. (2016) and Akkiz et al. (2010) have shown the association of MDM2 T309G polymorphism with HCC susceptibility $[25,26]$. Our results were also consistent with the results of Japanese [23], Moroccan [32], Korean [24], and Chinese populations [27]. On the other hand, Leu et al. (2009) found no association between

Table 3. Odds Ratios (OR) of HCC for MDM2 (T309G) Genotypes

\begin{tabular}{lcccc}
\hline Genotypes & Control $(\mathrm{N}=110)$ & Patients $(\mathrm{N}=100)$ & p value & OR (95\%, CI) \\
\hline TT & 41 & 21 & - & $1($ Ref. $)$ \\
TG & 51 & 46 & ns & $1.8(0.91-3.40)$ \\
GG & 18 & 33 & $<0.01$ & $3.6(1.64-7.80)$ \\
GG+TG & 69 & 79 & $<0.05$ & $2.2(1.21-4.14)$ \\
\hline
\end{tabular}

Results expressed as number. Fisher's exact test was done to evaluate significance among genotypic groups. 95\% CI; 95\% confidence interval; $p<0.05$ was taken as level of significance; ns, not significant. 
the MDM2 T309G genotypes and HCC susceptibility in the Taiwanese population [28]. The apparent lack of association of the study conducted by Leu et al. (2009) may result from a low sample size as well as unmatched age and gender of the study population [28]. In addition, the contribution of genetic polymorphisms to the risk for cancer may depend on environmental factors, geographic and ethnic differences.

As MDM2 has been evidenced to interact with several key tumor suppressors, including RB [11] and p53 [16], MDM2 polymorphism might affect cancer risk in several ways. First of all, MDM2 is a vital regulator of the TP53 pathway that facilitates the degradation of TP53, and over expression or augmentation of MDM2 has been frequently reported in almost all forms of human cancer types [33]. Secondly, the over expression of MDM2 has been associated with the susceptibility to carcinogenesis in genetically modified animals. Jones et al. (1998) showed that the MDM2-transgenic mice produce four-fold more MDM2 developed spontaneous tumors while transgenic mice with normal MDM2 levels did not develop tumors [34]. Thirdly, the binding affinity of Sp1 to the promoter of MDM2 is augmented by the G allele at 309 position ofMDM2 gene, increasing the cellular activity of MDM2 that abolished TP53 DNA damage response [17]. Therefore, considering the role of MDM2 in cancer formation, one might assume that individuals carrying the G allele may have a high level of MDM2 over a lifetime and would be at higher risk for developing hepatocellular carcinoma and other cancer.

In conclusion, this study provides evidence that polymorphism in MDM2 is associated with the risk of developing hepatocellular cancer in the Bangladeshi population. The G allele of MDM2 T309G could serve as an important marker to identify a higher risk of HCC. These results support the hypothesis that naturally occurring genetic variation in the tumor suppressor TP53 pathway may associate with cancer susceptibility. However, as this is the first report concerning the MDM2 polymorphism and the risk of HCC in the Bangladeshi population, independent studies with a large sample size are needed to validate our findings.

\section{Acknowledgments}

We would like to acknowledge the support and cooperation of the participants of this study. This research did not receive any specific grant from funding agencies in the public, commercial, or not-for-profit sectors.

\section{Conflict of interest}

The authors reported that there is no conflict of interest.

\section{References}

1. Parkin DM, Bray F, Ferlay J, Pisani P. Global Cancer Statistics, 2002. CA: A Cancer Journal for Clinicians. 2005 03 01;55(2):74-108. https://doi.org/10.3322/canjclin.55.2.74

2. Farazi PA, DePinho RA. Hepatocellular carcinoma pathogenesis: from genes to environment. Nature Reviews Cancer. 2006 09;6(9):674-687. https://doi.org/10.1038/ nrc1934

3. McKillop IH, Moran DM, Jin X, Koniaris LG. Molecular Pathogenesis of Hepatocellular Carcinoma. Journal of Surgical Research. 2006 Nov;136(1):125-135. https://doi. org/10.1016/j.jss.2006.04.013

4. Thorgeirsson SS, Grisham JW. Molecular pathogenesis of human hepatocellular carcinoma. Nature Genetics. 2002 08;31(4):339-346. https://doi.org/10.1038/ng0802-339

5. El-Serag HB, Rudolph KL. Hepatocellular Carcinoma: Epidemiology and Molecular Carcinogenesis. Gastroenterology. 2007 06;132(7):2557-2576. https://doi. org/10.1053/j.gastro.2007.04.061

6. Kirk GD. Hepatocellular Carcinoma and Polymorphisms in Carcinogen-Metabolizing and DNA Repair Enzymes in a Population with Aflatoxin Exposure and Hepatitis B Virus Endemicity. Cancer Epidemiology Biomarkers \& Prevention. 200502 01;14(2):373-379. https://doi. org/10.1158/1055-9965.epi-04-0161

7. Jung YJ, Kim YJ, Kim LH, Lee SO, Park BL, Shin HD, Lee $\mathrm{H}$. Putative Association of $<\mathrm{i}>\mathrm{Fas}</ \mathrm{i}>$ and $<\mathrm{i}>\mathrm{FasL}</ \mathrm{i}>$ Gene Polymorphisms with Clinical Outcomes of Hepatitis B Virus Infection. Intervirology. 2007;50(5):369-376. https:// doi.org/10.1159/000109751

8. Mayo LD, Donner DB. The PTEN, Mdm2, p53 tumor suppressor-oncoprotein network. Trends in Biochemical Sciences. 2002 09;27(9):462-467. https://doi.org/10.1016/ s0968-0004(02)02166-7

9. Harris SL, Levine AJ. The $\mathrm{p} 53$ pathway: positive and negative feedback loops. Oncogene. 2005 04;24(17):2899-2908. https://doi.org/10.1038/sj.onc. 1208615

10. Bálint E, Bates S, Vousden KH. Mdm 2 binds $p 73 \alpha$ without targeting degradation. Oncogene. 1999 07;18(27):39233929. https://doi.org/10.1038/sj.onc.1202781

11. Xiao Z, Chen J, Levine AJ, Modjtahedi N, Xing J, Sellers WR, Livingston DM. Interaction between the retinoblastoma protein and the oncoprotein MDM2. Nature. 1995 06;375(6533):694-698. https://doi.org/10.1038/375694a0

12. Calabrò V, Mansueto G, Parisi T, Vivo M, Calogero RA, La Mantia G. The Human MDM2 Oncoprotein Increases the Transcriptional Activity and the Protein Level of the p53 Homolog p63. Journal of Biological Chemistry. 2002 01;277(4):2674-2681. https://doi.org/10.1074/jbc. $\mathrm{m} 107173200$

13. Freedman DA, Wu L, Levine AJ. Functions of the MDM2 oncoprotein. Cellular and Molecular Life Sciences CMLS. 1999 01;55(1):96-107. https://doi.org/10.1007/ s000180050273

14. Moll UM and Petrenko O (2003). The MDM2-p53 interaction. Mol Cancer Res, 1, 1001-8.

15. Haupt Y, Maya R, Kazaz A, Oren M. Mdm2 promotes the rapid degradation of p53. Nature. 1997 05;387(6630):296299. https://doi.org/10.1038/387296a0

16. Momand J and Zambetti GP (1997). Mdm-2: 'big brother' of p53. J Cell Biochem, 64, 343-52.

17. Bond GL, Hu W, Bond EE, Robins H, Lutzker SG, Arva NC, Bargonetti J, Bartel F, Taubert H, Wuerl P, Onel K, Yip L, Hwang S, Strong LC, Lozano G, Levine AJ. A Single Nucleotide Polymorphism in the MDM2 
Promoter Attenuates the p53 Tumor Suppressor Pathway and Accelerates Tumor Formation in Humans. Cell. 2004 Nov;119(5):591-602. https://doi.org/10.1016/j. cell.2004.11.022

18. Zhang X, Miao X, Guo Y, Tan W, Zhou Y, Sun T, Wang $\mathrm{Y}$, Lin D. Genetic polymorphisms in cell cycle regulatory genesMDM2 andTP53 are associated with susceptibility to lung cancer. Human Mutation. 2005;27(1):110-117. https:// doi.org/10.1002/humu.20277

19. Ohmiya N, Taguchi A, Mabuchi N, Itoh A, Hirooka Y, Niwa Y, Goto H. MDM2Promoter Polymorphism Is Associated With Both an Increased Susceptibility to Gastric Carcinoma and Poor Prognosis. Journal of Clinical Oncology. 200609 20;24(27):4434-4440. https://doi.org/10.1200/ jco.2005.04.1459

20. Lind H, Zienolddiny S, Ekstrøm PO, Skaug V, Haugen A. Association of a functional polymorphism in the promoter of theMDM2 gene with risk of nonsmall cell lung cancer. International Journal of Cancer. 200608 01;119(3):718-721. https://doi.org/10.1002/ijc. 21872

21. Walsh CS, Miller CW, Karlan BY, Koeffler HP. Association between a functional single nucleotide polymorphism in the MDM2 gene and sporadic endometrial cancer risk. Gynecologic Oncology. 2007 03;104(3):660-664. https:// doi.org/10.1016/j.ygyno.2006.10.008

22. Onat OE, Tez M, Ozcelik T et al (2006). MDM2 T309G polymorphism is associated with bladder cancer. Anticancer Res, 26, 3473-5.

23. Dharel N, Kato N, Muroyama R, Moriyama M, Shao R, Kawabe T, Omata M. MDM2 Promoter SNP309 Is Associated with the Risk of Hepatocellular Carcinoma in Patients with Chronic Hepatitis C. Clinical Cancer Research. 200608 15;12(16):4867-4871. https://doi.org/10.1158/10780432.ccr-06-0111

24. Yoon YJ, Chang HY, Ahn SH, Kim JK, Park YK, Kang DR, Park JY, Myoung SM, Kim DY, Chon CY, Han K. MDM2 and $\mathrm{p} 53$ polymorphisms are associated with the development of hepatocellular carcinoma in patients with chronic hepatitis $\mathrm{B}$ virus infection. Carcinogenesis. 200804 15;29(6):11921196. https://doi.org/10.1093/carcin/bgn090

25. Qiu M, Liu Y, Yu X, Qin L, Bei C, Zeng X, Qiu X, Tang B, $\mathrm{He} \mathrm{S}, \mathrm{Yu} \mathrm{H}$. Interaction between $\mathrm{p} 53$ codon 72 and MDM2 309T $>\mathrm{G}$ polymorphisms and the risk of hepatocellular carcinoma. Tumor Biology. 2015 Oct 17;37(3):3863-3870. https://doi.org/10.1007/s13277-015-4222-4

26. Akkız H, Sümbül AT, Bayram S, Bekar A, Akgöllü E. MDM2 promoter polymorphism is associated with increased susceptibility to hepatocellular carcinoma in Turkish population. Cancer Epidemiology. 2010 08;34(4):448-452. https://doi.org/10.1016/j.canep.2010.04.008

27. Jiang D (2008). p53 gene mutation, p53 R72P and MDM2 SNP309 polymorphisms and hepatocellular carcinoma development and prognosis [D]. Fudan University, 121-3.

28. Leu J, Lin I, Sun Y, Chen S, Liu C, Lee Y. Association between MDM2-SNP309 and hepatocellularcarcinoma in Taiwanese population. World Journal of Gastroenterology. 2009;15(44):5592. https://doi.org/10.3748/wjg.15.5592

29. World Medical Association Declaration of Helsinki. JAMA. 2013 Nov 27;310(20):2191. https://doi.org/10.1001/ jama.2013.281053

30. Hosen MB, Salam MA, Islam MF, Hossain A, Hawlader MZH, Kabir Y. Association of TP53 gene polymorphisms with susceptibility of bladder cancer in Bangladeshi population. Tumor Biology. 201503 25;36(8):6369-6374. https://doi.org/10.1007/s13277-015-3324-3

31. Bailes S, Devers J, Kirby J, Rhoads D. An Inexpensive,
Simple Protocol for DNA Isolation from Blood for HighThroughput Genotyping by Polymerase Chain Reaction or Restriction Endonuclease Digestion. Poultry Science. 2007 01;86(1):102-106. https://doi.org/10.1093/ps/86.1.102

32. Ezzikouri S, El Feydi AE, Afifi R, El Kihal L, Benazzouz M, Hassar M, Marchio A, Pineau P, Benjelloun S. MDM2 SNP309T $>$ G polymorphism and risk of hepatocellular carcinoma: A case-control analysis in a Moroccan population. Cancer Detection and Prevention. 2009 01;32(56):380-385. https://doi.org/10.1016/j.cdp.2009.01.003

33. Oliner JD, Kinzler KW, Meltzer PS, George DL, Vogelstein B. Amplification of a gene encoding a p53- analysis in a Moroccan population sarcomas. Nature. 1992 07;358(6381):80-83. https://doi.org/10.1038/358080a0

34. Jones SN, Hancock AR, Vogel H, Donehower LA, Bradley A. Overexpression of Mdm2 in mice reveals a p53-independent role for Mdm2 in tumorigenesis. Proceedings of the National Academy of Sciences. 1998 Dec 22;95(26):15608-15612. https://doi.org/10.1073/pnas.95.26.15608

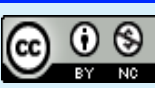

This work is licensed under a Creative Commons AttributionNon Commercial 4.0 International License. 